\title{
Detection of Some Types of Bacteria in Patients with Kidney Stones and the Use of Corn Silk Extracts to Effectively Inhibit the Urease Enzyme in Klebsiella Species
}

\author{
Maha A. Naif ${ }^{1^{*}}$ and Rafah H. Ismail ${ }^{2}$ \\ ${ }^{1}$ Department of Biology, Collage of Science, University of Baghdad, Baghdad, Iraq \\ ${ }^{2}$ Department of Chemistry, Collage of Science, Al-Nahrain University, Baghdad, Iraq \\ *Corresponding author
}

\section{A B S T R A C T}

\begin{tabular}{|l|}
\hline K e y w o r d s \\
$\begin{array}{l}\text { Kidney stones, Corn silk } \\
\text { extracts, Urease enzyme, } \\
\text { Klebsiella species }\end{array}$ \\
\hline Article Info \\
\hline $\begin{array}{l}\text { Accepted: } \\
\text { 06 July } 2018 \\
\text { Available Online: } \\
\text { 10 August } 2018\end{array}$ \\
\hline
\end{tabular}

\section{Introduction}

\section{Nephrolithiasis}

Renal stones are a common clinical problem with a subsequent burden for the health system (Aggarwal et al., 2013). It is one of the most common painful disease (Sekkoum et al., 2016). The symptoms related to the renal stones are highly dependent on the stones locations, the stones located within calyces are considered to be asymptomatic. While the initial symptoms of stone existing in the ureter are a cute onset of severe flank pain probably associated with nausea, vomiting and hematuria (Perera, 2016). There are four main
This paper was carried out for detection some types of bacteria in patients with kidney stones and the use of corn silk extracts to effectively inhibit the urease enzyme in Klebsiella Species. However, the urine culture was performed for 100 patients with kidney stones, making sure that the patients did not take any anti - bacterial medication. The results showed that $71 \%$ of the patients have no growth in their urine culture and $29 \%$ have positive urine culture $(13 \%, 10 \%, 5 \%$ and $1 \%$ of Klebsiella, E. coli, Proteus, and Pseudomonas) respectively. All such extracts revealed an effective inhibition of urease (he Klebsiella species with (IC50 = 235.9, 305.5 and $247.3 \mathrm{mg} / \mathrm{L}$ ) for $99.9 \%$ ethanol, $80 \%$ ethanol and aqueous extracts respectively, while standard urease inhibitor exhibits $(\mathrm{IC} 50=138.1 \mathrm{mg} / \mathrm{L})$ for thiourea (TU) as an example.

types of kidney stones; calcium stones, uric acid stones, struvite stones, and cysteine stones (Wang et al., 2017).

Struvite kidney stones or another name "infection stones" which have a proportion about $(10-15 \%)$ of all kidney stones. are known to occur more frequently in women than in men (at a 2:1 ratio) a finding that might be attributable to the higher incidence of urinary tract infection (UTI) in women (Flannigan et al., 2014). Struvite calculi are important clinically because they can lead to sepsis and renal failure (Pang et al., 2015). In fact these stones are mainly composed of magnesium ammonium phosphate 
$\mathrm{MgNH}_{4} \mathrm{PO}_{4} \cdot 6 \mathrm{H}_{2} \mathrm{O}$ (struvite) and calcium carbonate apatite $\mathrm{Ca}_{10}\left(\mathrm{PO}_{4}\right)_{6} \cdot \mathrm{CO}_{3}$ (Iqbal et al., 2016). The urine composition does not seem to be a factor inthe spontaneous formation of struvite crystals; therefore, stones containing struvite are considered associated with (UTI) (Bazin et al., 2012). They are primarily caused by urea splitting bacteria such as Proteus, Pseudomonas, Klebsiella and Staphylococcus (Macegoniuk, 2013).

\section{Corn silk}

Today, researchers have focused on the drug discovery from medicinal plants Medicinal plants are regarded as an acceptable, cheap, easily available and safe source of active compounds for pharmaceutical (Bahmani et al., 2016). Corn silk is a long, weak, and shiny fibers at the top of corn's ear (Hu et al., 2010). Traditionally, it is used for making tea as a healthy and medical drink in Asian communities especially in China (Cuina et al., 2011). However, corn silk becomes very important in drugs development, because of its bioactive constituents which include oxidant prevention agent limits, anti-diabetic activity anti-proliferative effects diuretic activity anticoagulant activity, antifungal, anti-fatigue, and treating obesity (Chen et al., 2013).

\section{Materials and Methods}

\section{Patients}

The present study comprised of 100 individuals patient with kidney stones (group1) (60 male and 40 female). Patients aged from 20 to 75 years old, were attending to the urologic department in Ghazi Al-Hariri Hospital for the period from December 2016 to February 2017, Patients were diagnosed by urologist in the hospital. Patients didn't Suffers from any other disease. The urine samples were collected to done general urine examination and urine cultures

\section{The bacteriology}

Culture of urine for 100 patients with kidney stone (group 1)

Performed on MacConkey agars, inoculating $0.001 \mathrm{~mL}$ of urine and streaking the surface to quantitative colony counts. The plates were aerobically incubated for $24 \mathrm{hr}$. at $35^{\circ} \mathrm{C}$.

Identification of bacteria in urine of $\mathbf{1 0 0}$ patients with kidney stone (group 1)

Identification of suspected isolates were done according to the colony morphology and biochemical tests.

\section{Colony morphology}

All isolates were primarily identified according to the general culture characteristic (color, shape, texture and size) of the colony onto MacConky agar and eosin methylene blue EMB agar after incubated overnight at $37^{\circ} \mathrm{C}$. Other characteristics were observed like lactose fermentation.

Biochemical tests to identify bacteria in urine of patients with kidney stone

Following tests were used to identify bacteria.

\section{Citrate utilization test}

Simmon citrate agar slant was stabbed with fresh bacterial isolates and incubated at $37{ }^{\circ} \mathrm{C}$ for $24 \mathrm{hrs}$. Changing the color from green to blue is indicating a positive result. This test used to detect the bacterial ability to utilize sodium citrate as a carbon source.

\section{Oxidase test reagent}

A filter paper was moistened with several drops of freshly prepared $1 \%$ oxidase reagent, and then a small portion of the tested colony 
was picked up by a wooden stick and placed on moistened filter paper. The color conversion to blue or purple color within 30 second this indicated to a positive reaction.

\section{Motility test}

Tube containing motility media was stabbed once in the center of media with an inoculating needle, then incubated at $37^{\circ} \mathrm{C}$ for $24 \mathrm{hrs}$. The motile bacteria spread out from the injected line of inoculation.

\section{Urease test}

Urea agar slant was inoculated heavily over the entire slant surface and incubated at $37^{\circ} \mathrm{C}$ for $24 \mathrm{hrs}$. Urease test is positive if the indicator was changed to purple-pink color, while keeping the media its yellow-orange color indicates a negative result. This test used to detect bacterial capacity to produce urease enzyme which hydrolyzes urea to ammonia and carbon dioxide.

\section{Indole test}

Peptone broth was inoculated with a new culture of each suspected isolate and incubated at $37^{\circ} \mathrm{C}$ for $24 \mathrm{hrs}$. Avolume of $0.5 \mathrm{ml}$ from Kovac's reagent, was added directly to the bacterial culture tube and if the culture produces tryptophanse which hydrolyze tryptophan to indole, pyruvic acid and ammonia, red ring will appear at the top of the broth and this indicated a positive result.

\section{Storage of bacteria}

The bacteria storage in Brain heart infusion.

\section{Extraction of corn silk part}

\section{Plant materials}

The samples of corn plant were collected at harvesting time where their materials are fully maturated and developed. Firstly, the corn silk flowers were gathered from corn fields of the faculty of Agriculture's farm of Baghdad University in February 2017. Secondly, they were dried in a shaded well-ventilated place. Thirdly, Cuts $(0.4 \mathrm{~mm})$ them using a knife mills then keeping them stored in glass containers at room temperature for further processing (Liu et al., 2011).

\section{Preparation of the crude extract (Liu et al., 2011)}

Three Erlenmeyer flask labelled with $99.9 \%$ ethanol extract, $80 \% \mathrm{v} / \mathrm{v}$ ethanol/water extract and water extract contain 1L of $99 \%$ ethanol, $80 \% \mathrm{v} / \mathrm{v}$ ethanol/water and water respectively

One hundred $\mathrm{g}$ of chopped corn silk were added to each flask and exposed to a hot continuous extraction in a Ultrasonic at steady temperature of $\left(50 \pm 1.0{ }^{\circ} \mathrm{C}\right)$ for 5 hours (cycles 1)

Decanted the solvents from each flask, added 1L of each solvents and exposed to a hot continuous extraction in a Ultrasonic at steady temperature of $\left(50 \pm 1.0{ }^{\circ} \mathrm{C}\right)$ for 5 hours (cycles2)

\section{Repeat step 3 (cycles3)}

Each of three previous extracts was filtered through Whatman No. 1 filter paper to remove the debris.

Then, each filtered sample was condensed by a rotary flash evaporator under vacuum at $50^{\circ} \mathrm{C}$.

Lyophilizing each condensed samples in a freeze-dryer to obtain a crude $99.9 \%$ ethanol Extract $(99.9 \% \mathrm{EE}), 80 \%$ ethanolic extract $(80 \% \mathrm{EE})$, and water extract (AE).

Lastly, all extracts were stored at $4{ }^{\circ} \mathrm{C}$ for subsequent analysis 
The same experiment was returned to the one hundred $\mathrm{g}$ of the corn silk powder which was crushed by the electric mill with $80 \%$ ethanol.

\section{Calculation:}

The below equation used to determine the yield as percentage of the quantity of the initial material of $(100 \mathrm{~g})$.

Yield $\%=\frac{\text { yield } * 100}{100 \mathrm{~g}}$

\section{Urease inhibition part}

\section{Preparation concentration}

Prepared the stock solutions of organic solutions by dissolve organic extracts dried and aqueous extract dried by phosphateBuffered ( $\mathrm{pH}=7)$

Prepared from it various concentration (1000, 500, 250, 125, 62.5) $\mathrm{mg} \backslash \mathrm{L}$ diluted with phosphate-Buffered $(\mathrm{pH}=7)$ for organic extract and aqueous extract.

Then filter it with micro filter $0.45 \mu \mathrm{m}$ and used or stored at $4 \mathrm{C}^{\circ}$ until further use.

\section{Klebsiella species urease inhibition assay}

\section{Activation of microorganisms}

The specimen of the colonies was taken by a loop that contains $5 \mathrm{ml}$ of sterilized Brain heart agar. The loop has been shaken well and incubated in the incubator for 24 hours at 37 ${ }^{\circ} \mathrm{C}$. The loop was sterilized via flame before using it to ensure that the planted bacteria are not contaminated

\section{Principle of urease inhibition assay}

The inhibition of urease examination was performed spectrophotometrically in 96-well
Microplate, Urease activity was continuously measured with the rate of ammonia generation.

\section{Procedure of urease inhibition assay}

Dissolve $38.71 \mathrm{~g}$ of urea broth powder in 1000 $\mathrm{ml}$ distilled water.

Then, thoroughly mix to dissolve the medium completely then sterilize the results by Autoclave.

After that, $40 \%$ urea was sterilized by filtration and added to the medium.

After activation, under a sterile tube and aseptic ambience, the desired colony was taken by a loop to the test tube that contains 5 $\mathrm{ml}$ of the sterilized urea broth

The solution: $(100 \mu 1)$ of bacteria diluted of Klebsiella species was incubated with $100 \mu 1$ of extracts $(99.9 \% \mathrm{EE}),(80 \% \mathrm{EE})$, and (AE) dissolved in phosphate puffer in concentrations of $(1000,500,250,125,62.5$, and $31.25 \mathrm{mg} / \mathrm{L}$ ) at $30{ }^{\circ} \mathrm{C}$ for 24 hour.

Change in absorbance (optical density) was measured at $630 \mathrm{~nm}$ on ELISA plate reader in compare with standard urease inhibitor i.e. thiourea (TU) (Awllia et al., 2016).

\section{Calculation}

The percentage of inhibition was calculated by using the formula given below.

$\%$ Inhibition $=100-\left\{\frac{\text { Absorbance of Test Compound }}{\text { Absorbance of Control }} \times 100\right\}$

Measuring the effects of different concentrations of inhibitors on production of ammonia was used to evaluate the IC50 of the active compounds are calculated by plotting the relation between $\%$ Inhibition and 
concentration of inhibitors. The IC50 values were determined using Graphpad Prism7 software.

\section{Results and Discussion}

\section{Result of urine culture}

The urine culture was performed for 100 patients with kidney stones, making sure that the patients did not take any anti - bacterial medication. The results showed that $71 \%$ of the patients have no growth in their urine culture and $29 \%$ have positive urine culture (13\%, $10 \%, 5 \%$ and $1 \%$ of Klebsiella, E-coli, Proteus, and Pseudomonas) respectively. All results of urine culture are shown in Table 1.

Ureolytic infection- induced stones are estimated to constitute 15-20\% of all urinary stones. Proteus, Pseudomonas, and Klebsiella are the most common bacterium responsible for struvite stone (Krajewska, 2009). Escherichia coli causes the majority of asymptomatic bacteriuria, cystitis, pyelonephritis, and catheter-associated urinary tract infection (UTI)

\section{Diagnosis of bacteria}

Primary bacteria identification with nonspecific media MacConkey agar show in Table 2, is a selective and differential culture medium for bacteria designed to selectively isolate Gram-negative. Klebsiella, Proteus, Ecoli, and Pseudomonas they have growth on MacConkey agar. MacConkey agar distinguishes those Gram-negative bacteria that can ferment the sugar lactose (Lac+) from those that cannot (Lac-) fermentation. Klebsiella and E.coli are lactose fermenting. The bile salts precipitate in the immediate neighbourhood of the colony, causing the medium surrounding the colony to become hazy. Proteus and Pseudomonas are Nonlactose fermenting. Table 3 shows bacteria identification in Citrate utilization test, indole test, Oxidase test, motility test and Urease test.

\section{Plant extract}

\section{Extraction of corn silk}

Table 4 shows yield of extracts of corn silk with respect to solvents. The percentage yields were calculated against $100 \mathrm{~g}$ of corn silk material subjected to each extraction method. The percentage yield of aqueous extract (AE) (was high yield than others $9.1 \%$. The next was $80 \%$ ethanol extract $(80 \% \mathrm{EE})$ with $(2.4 \%)$. The percentage was $(0.93)$ for $99.9 \%$ ethanol extract $(99.9 \% \mathrm{EE})$. These results disagree with those reported by (Nurhanan et al., 2012) who mention that the yield of extracts is found to be in ethanol higher than water. However, more polar aglycones or flavonoid glycosides are extracted with pure alcohols or with water-alcohol mixtures, and for less polar flavonoids (isoflavones, flavanones, methylated flavones, and flavonols) (Liu et al., 2011)

According to the results shown in Table 4, it is noticed that the water solvent gives higher yield than others which can considered as factor in solvent cost reduction. When we returned the experiment to the powder of the corn silk which was crushed by the electric mill with $80 \%$ ethanol the yield of extracts was only $0.84 \mathrm{~g}$, however, the yield of extracts of powder of the corn silk less than yield of extracts of cut corn silk $(0.4 \mathrm{~mm})$ because when the particle sizes are too small, unhomogeneous extractions can form and the analyte re-adsorption on the matrix surfaces, which hinders the extraction. In our study, because of the re-adsorption of the extracted solutes, a lower flavonoid yield was found when the particle size was smaller than $0.4 \mathrm{~mm}$. Hence, a particle size of $0.4 \mathrm{~mm}$ was selected for subsequent tests (Razmara et al., 2010). 
Table.1 Bacteria types and Percentage in urine culture

\begin{tabular}{|l|}
\hline bacteria types \\
\hline Klebsiella \\
\hline Proteus \\
\hline E.coli \\
\hline Pseudomonas \\
\hline No growth \\
\hline
\end{tabular}

\begin{tabular}{|l|}
\hline Percentage \\
\hline $13 \%$ \\
\hline $5 \%$ \\
\hline $10 \%$ \\
\hline $1 \%$ \\
\hline $71 \%$ \\
\hline
\end{tabular}

Table.2 The Primary bacteria identification with MacConkey agar

\begin{tabular}{|l|}
\hline bacteria species \\
\hline Klebsiella \\
\hline Proteus \\
\hline E.coli \\
\hline Pseudomonas
\end{tabular}

MacConKey Aga
Positive(+)
Positive(+)
positive(+)
Positive(+)

ferment the sugar lactose

Lac+

Lac-

Lac+

Lac-

Table.3 Bacteria identification with, Citrate utilization test indole test, Oxidase test, motility test and Urease test

\begin{tabular}{|c|c|c|c|c|c|}
\hline & $\begin{array}{l}\text { Citrate } \\
\text { utilization test }\end{array}$ & Indole test & $\begin{array}{l}\text { Oxidase } \\
\text { test }\end{array}$ & $\begin{array}{l}\text { Motility } \\
\text { test }\end{array}$ & Urease test \\
\hline Klebsiella & $\begin{array}{l}\text { Positive }(+) \\
\text { (blue color) }\end{array}$ & $\begin{array}{l}\text { Positive(+) } \\
\text { or Negative(-) }\end{array}$ & Negative(-) & Negative(-) & Positive(+) \\
\hline Protuse & $\begin{array}{l}\text { Negative(-) } \\
\text { (green color) }\end{array}$ & $\begin{array}{l}\text { Positive(+) } \\
\text { or Negative(-) }\end{array}$ & Negative(-) & Positive(+) & Positive(+) \\
\hline E-coli & $\begin{array}{l}\text { Negative(-) } \\
\text { (green color) }\end{array}$ & positive(+) & Negative(-) & Positive(+) & Negative(-) \\
\hline Pseudomonas & $\begin{array}{l}\text { Positive(+) } \\
\text { (blue color) }\end{array}$ & Negative(-) & Positive(+) & Negative(-) & Negative(-) \\
\hline
\end{tabular}

Table.4 Comparison analysis of extraction yield, in $100 \mathrm{~g}$ of corn silk. Fractions obtained using different solvents

\begin{tabular}{|l|l|l|l|}
\hline $\begin{array}{l}\text { Type of solvents used in } \\
\text { extraction }\end{array}$ & Yield(g) & $\begin{array}{l}\text { Color } \\
\text { extract }\end{array}$ & yield\% \\
\hline \begin{tabular}{l} 
99.9\% ethanol \\
\hline $80 \%$ ethanol
\end{tabular} & $\mathbf{0 . 9 3}$ & $\begin{array}{l}\text { yellow } \\
\text { light brown }\end{array}$ & $\mathbf{0 . 9 3 \%}$ \\
\hline Water & $\mathbf{2 . 4}$ & brown & $\mathbf{9 . 1 \%}$ \\
\hline
\end{tabular}


Table.5 Klebsiella species urease inhibitory activity of Extracts (99.9\%EE) (80\%EE), (AE) as compared with standard urease inhibitor thiourea

\begin{tabular}{|c|c|c|c|c|}
\hline $\begin{array}{c}\text { Conc. } \\
\text { species }\end{array}$ & $\begin{array}{c}\text { Inhibition \% of } \\
\text { thiourea }\end{array}$ & $\begin{array}{c}\text { Inhibition \% of } \\
\text { 99.9E.E. }\end{array}$ & $\begin{array}{c}\text { Inhibition \% of } \\
80 \% \text { E.E. }\end{array}$ & $\begin{array}{c}\text { Inhibition \% of } \\
\text { A.E. }\end{array}$ \\
\hline 31.25 & $\mathbf{2 9 . 7 8}$ & 23.72 & $\mathbf{9 . 9 2 7}$ & $\mathbf{2 8 . 8 1}$ \\
\hline 62.5 & $\mathbf{3 4 . 6 2}$ & $\mathbf{2 9 . 5 3}$ & $\mathbf{2 3 . 9 7}$ & $\mathbf{3 4 . 6 2}$ \\
\hline 125 & $\mathbf{3 8 . 2 5}$ & $\mathbf{3 3 . 8 9}$ & $\mathbf{3 1 . 2 3}$ & $\mathbf{3 7 . 7 7}$ \\
\hline 250 & $\mathbf{3 9 . 7 0}$ & $\mathbf{3 8 . 9 8}$ & $\mathbf{3 2 . 6 2}$ & $\mathbf{3 9 . 2 2}$ \\
\hline 500 & $\mathbf{4 5 . 7 6}$ & 41.64 & $\mathbf{3 6 . 2 5}$ & $\mathbf{4 0 . 6 7}$ \\
\hline 1000 & $\mathbf{5 2 . 3 0}$ & 44.30 & $\mathbf{4 2 . 4 2}$ & $\mathbf{4 4 . 3 0 9 9}$ \\
\hline IC50 & $\mathbf{1 3 8 . 1}$ & $\mathbf{2 3 5 . 9}$ & $\mathbf{3 0 5 . 5}$ & $\mathbf{2 4 7 . 3}$ \\
\hline
\end{tabular}

Fig.1 The IC50 of Klebsiella species urease inhibition by thiourea

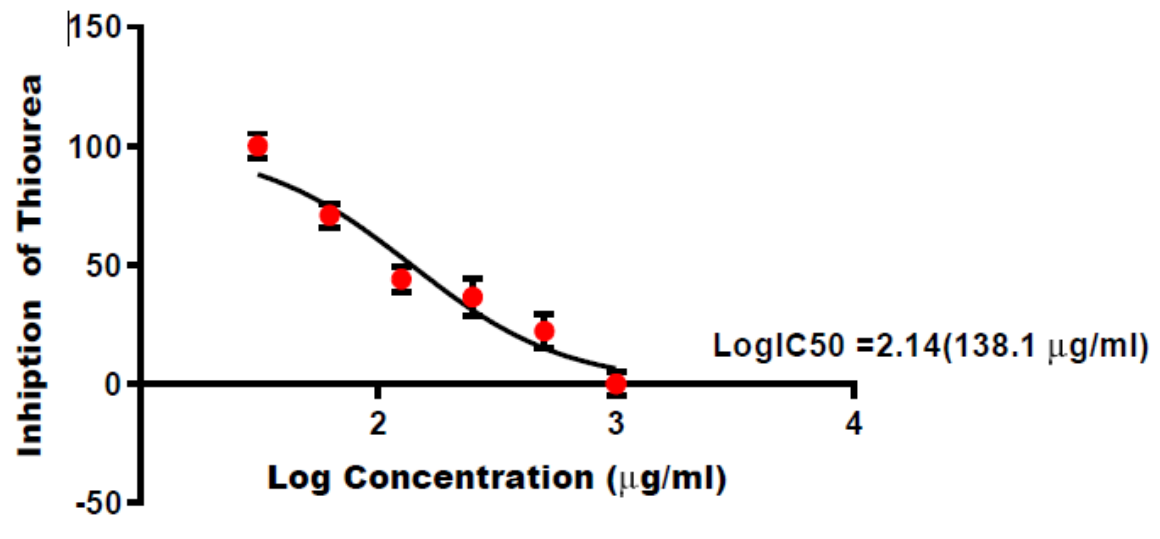

Fig.2 IC50 of Klebsiella species urease inhibition by different concentrations of $99.9 \%$ ethanolic extract $(99.9 \% \mathrm{EE})$

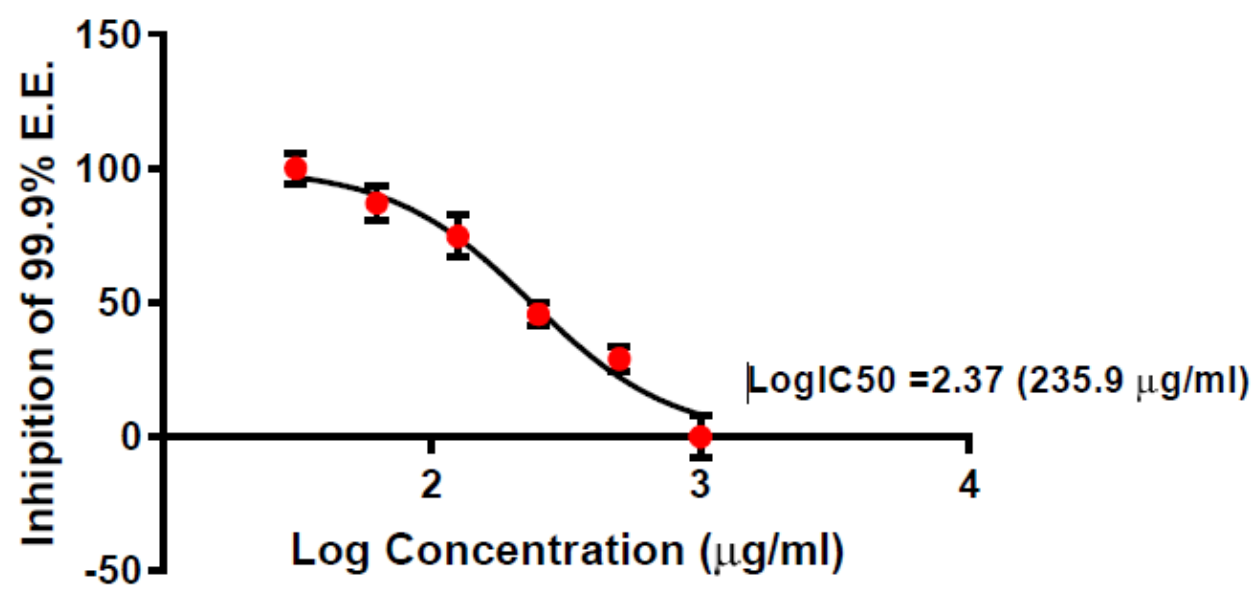


Fig.3 IC50 of Klebsiella species urease inhibition by different concentrations of 80\%ethanolic extract $(80 \% \mathrm{EE})$

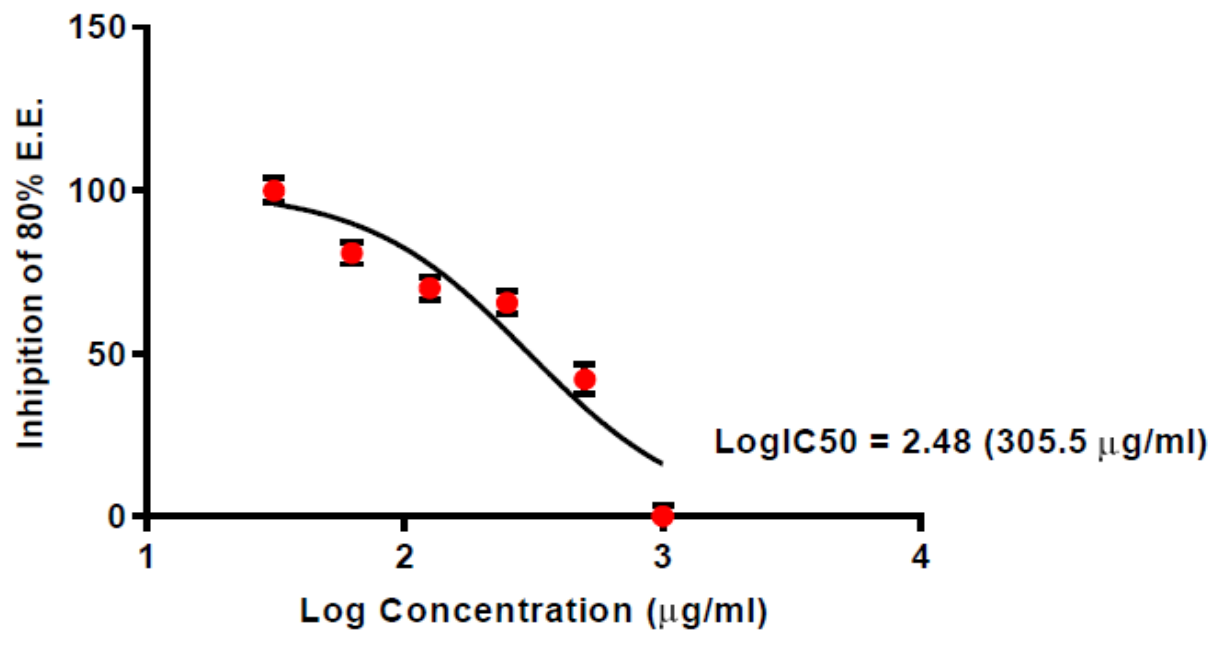

Fig.4 IC50 of Klebsiella species urease inhibition by different concentrations of aqueous extract (AE)

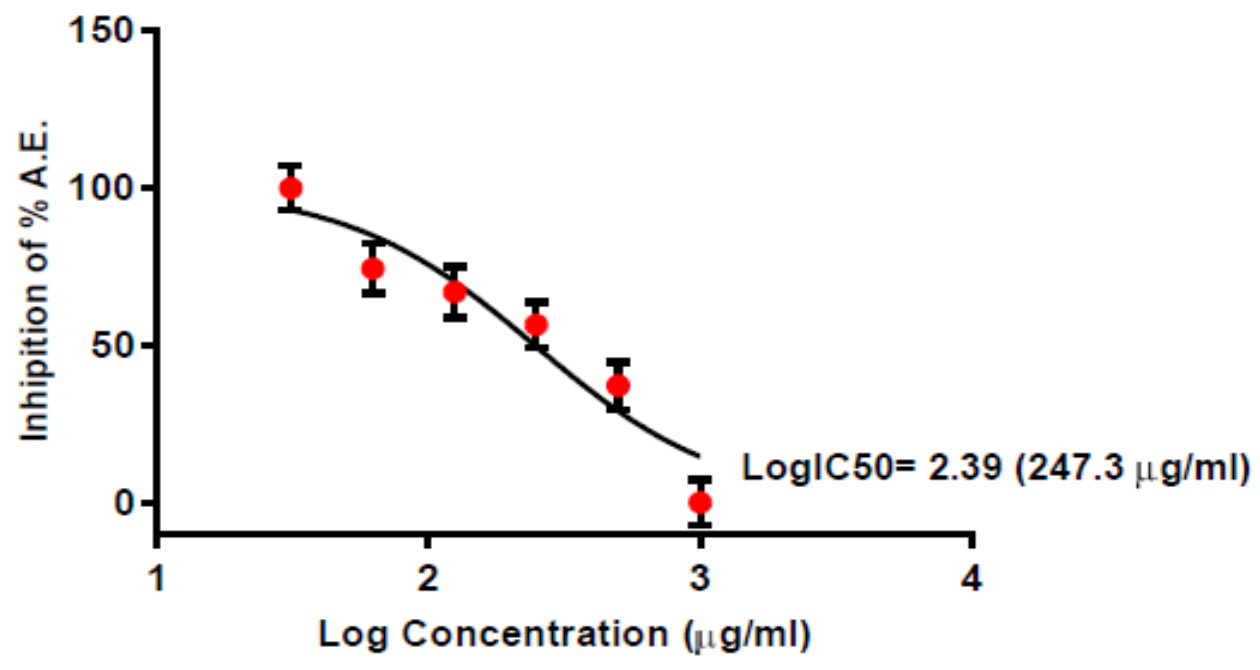

Study urease inhibition by corn silk extract

Studies on enzyme inhibition are an important area of pharmaceutical science. These studies in the past have led to the discoveries of several successful drugs, useful against a variety of pathophysiological conditions. Natural products have played an important role in the development of new therapeutic agents against urease enzyme, such as flavonoids, that exhibited excellent urease inhibitory activity. Specific inhibitors interact 
with enzymes and block their activity towards their corresponding natural and synthetic substrates (Liu et al., 2011).

\section{Urease inhibition in Klebsiella species}

Urea Broth medium was developed by Rustigian and Stuart. This medium is especially recommended by Indian Pharmacopoeia. The pink color is given as a positive result of the bacteria produced urease Klebsiella aerogenes. Because Urea Broth Medium convert to alkaline as the use of urea by the organisms release ammonia through the incubation, showed by pink color (Mac Faddin, 1976) The inhibitory activity of Extracts $(99.9 \% \mathrm{EE}),(80 \% \mathrm{EE})$, and (AE) to Klebsiella Species are shown in the table 5. It is noticed that all three extracts $(99.9 \% \mathrm{EE})$, (80\%EE), and (AE) show a potent urease inhibitory activity and the IC50 values are shown in Figure 1, 2 and 3. (IC50 = 235.9, 305.5 , and $247.3 \mathrm{mg} / \mathrm{L})$ respectively as compared with Thio urea as shown in Figure 4, which shows inhibitory of (IC50 $=138.1 \mathrm{mg} / \mathrm{L})$. The extract $(99.9 \% \mathrm{EE})$ has less IC50 so it's the best urease inhibitor from the other extracts.

\section{References}

Aggarwal K. P., Narula, S., Kakkar, M., and Tandon, C. (2013). Nephrolithiasis: molecular mechanism of renal stone formation and the critical role played by modulators. BioMed research international, 1-21.

Awllia, A.J., J., Al-Ghamdi, M., Huwait, E., Javaid, S., Rasheed, S., and Iqbal Choudhary, M. (2016). Flavonoids as Natural Inhibitors of Jack Bean Urease Enzyme. Letters in Drug Design and Discovery, 13(3), 243-249

Bahmani, M., Baharvand-Ahmadi, B., Tajeddini, P., Rafieian-Kopaei, M., and Naghdi, N. (2016). Identification of medicinal plants for the treatment of kidney and urinary stones. Journal of renal injury prevention, 5(3), 129.

Bazin, D., André, G., Weil, R., Matzen, G., Emmanuel, V., Carpentier, X., and Daudon, M. (2012). Absence of bacterial imprints on struvite-containing kidney stones: a structural investigation at the mesoscopic and atomic scale. Urology, 79(4), 786-790.

Chen, S., Chen, H., Tian, J., Wang, Y., Xing, L., and Wang, J. (2013). Chemical modification, antioxidant and $\alpha$-amylase inhibitory activities of corn silk polysaccharides. Carbohydrate polymers, 98(1), 428-437.

Cuina, W., Tiehua, Z., Jun, L., Shuang, L., Cheng, Z., Erlei, W., and Jingbo, L. (2011). Subchronic toxicity study of corn silk with rats. J. Ethnopharmacol.

Flannigan, R., Choy, W. H., Chew, B., and Lange, D. (2014). Renal struvite stones - pathogenesis, microbiology, and management strategies. Nature reviews Urology, 11(6), 333-341.

Hu, Q. L., Zhang, L. J., Li, Y. N., Ding, Y. J., and Li, F. L. (2010). Purification and anti-fatigue activity of flavonoids from corn silk. International Journal of Physical Sciences, 5(4), 321-326.

Iqbal, M. W., Youssef, R. F., Neisius, A., Kuntz, N., Hanna, J., Ferrandino, M. N., and Lipkin, M. E. (2016). Contemporary management of struvite stones using combined endourologic and medical treatment: predictors of unfavorable clinical outcome. Journal of endourology, 30(7), 771-777.

Krajewska, B. (2009). Ureases I. Functional, catalytic and kinetic properties: A review. Journal of Molecular Catalysis B: Enzymatic, 59(1), 9-21.

Liu, J., Lin, S., Wang, Z., Wang, C., Wang, E., Zhang, Y., and Liu, J. (2011). Supercritical fluid extraction of flavonoids from Maydis stigma and its 
nitrite-scavenging ability. Food and bioproducts processing, 89(4), 333-339.

Liu, J., Wang, C., Wang, Z., Zhang, C., Lu, S., and Liu, J. (2011). The antioxidant and free-radical scavenging activities of extract and fractions from corn silk ( $\mathrm{Zea}$ mays L.) and related flavone glycosides. Food Chemistry, 126(1), 261-269

Mac Faddin, J. F. (1976). Biochemical tests for identification of medical bacteria. Williams and Wilkins Co.

Macegoniuk, K. (2013). Inhibitors of bacterial and plants urease. Folia Biologica et Oecologica, 9(1), 9-16

Nurhanan, A. R., and WI, W. R. (2012). Evaluation of Polyphenol Content and Antioxidant Activities of Some Selected Organic and Aqueous Extracts of Cornsilk (Zea Mays Hairs). Journal of Medical and Bioengineering (JOMB) Vol, 1(1).

Pang, J., Borjeson, T. M., Parry, N., and Fox, J. G. (2015). Struvite Urolithiasis in
Long-Evans Rats. Comparative medicine, 65(6), 486-491.

Perera, I. (2016). Renal stones in children: evaluation and medical management. Sri Lanka Journal of Child Health, 45(1), 3-10.

Razmara, R. S., Daneshfar, A., and Sahraei, R. (2010). Solubility of quercetin in water+ methanol and water+ ethanol from (292.8 to 333.8) K. Journal of Chemical and Engineering Data, 55(9), 3934-3936.

Sekkoum, K., Cheriti, A., Taleb, S., and Belboukhari, N. (2016). FTIR spectroscopic study of human urinary stones from El Bayadh district (Algeria). Arabian Journal of Chemistry, 9(3), 330-334.

Wang, X. G., Fan, B., Wang, W., Jin, Y. Y., Jin, Y., Yang, Z. Q., and Li, X. C. (2017). The value of performing dualsource dual-energy computed tomography in analysis strategy for urinary mixed stone. Int $\mathbf{J}$ ClinExpPathol, 10(2), 1519-1528

\section{How to cite this article:}

Maha A. Naif and Rafah H. Ismail. 2018. Detection of Some Types of Bacteria in Patients with Kidney Stones and the Use of Corn Silk Extracts to Effectively Inhibit the Urease Enzyme in Klebsiella Species. Int.J.Curr.Microbiol.App.Sci. 7(08): 545-554. doi: https://doi.org/10.20546/ijcmas.2018.708.060 